九州大学学術情報リポジトリ

Kyushu University Institutional Repository

\title{
THE GENUS ANTISPILA FROM JAPAN, WITH DESCRIPTIONS OF SEVEN NEW SPECIES (Lepidoptera, Heliozelidae)
}

Kuroko, Hiroshi

https://doi.org/10.5109/2347

出版情報: ESAKIA. 3, pp.11-24, 1961-08-05. Hikosan biological laboratory, Faculty of Agriculture, Kyushu University バージョン：

権利関係 : 


\title{
THE GENUS ANTISPILA FROM JAPAN, WITH DESCRIPTIONS OF SEVEN NEW SPECIES*
}

\author{
(Lepidoptera, Heliozelidae)
}

By

\section{Hiroshi Kuroko}

Antispila is a small genus, including only over thirty described species in the world. In Japan not a single species has hitherto been reported. In the present paper the author gives a key to the species, descriptions of seven new species on the basis of specimens which were gained by breeding of the larvae. The type specimens designated in the present paper are deposited in the collection of the Entomological Laboratory, Kyushu University.

Before going further the author wishes to express his hearty thanks to Prof. K. Yasumatsu for his constant direction ; to Dr. K. Sattler, of Zoologische Sammlung des bayerischen States for the gift of valuable specimens for comparison.

\section{Genus Antispila Hübner}

Antispila Hübner, 1825, Verz. bekannt. Schmett., (27) : 419; Stainton, 1870, Nat. Hist. Tin., 11: [298; Meyrick, 1895, Handb. Brit. Lep. : 683; Spuler, 1910, in Hofmann-Spuler, Schmett. Eur., 2 : 471; Hering, 1932, Tierwert Mitteleurop. 3: 15.

Type species: Antispila pfeifferella (Hiibner).

Head and face smooth; ocelli absent; tongue developed, naked. Antennae $1 / 2-2 / 3$ of forewing, thick, simple in both sexes. Labial palpi 3 jointed, short and thick, drooping, terminal joint pointed. Maxillary palpi are seen inside labial palpi and concealed by forntal scales, nearly $1 / 2$ the length of labial palpi. Posterior tibiae smooth, with long hairs beneath. Forewings broadIanceolate, with silvery or golden-metallic markings, namely, a transverse fascia or two opposite spots (anterior costal and dorsal-spots) at $1 / 3$, and two opposite

* Contribution Ser. 2, No. 11, Hikosan Biological Laboratory, Kyushu University, Hikosan.

Contribution Ser. 2, No. 99, Entomological Laboratory, Kyushu University, Fukuoka. 
spots (posterior costal and dorsal spots) at near $2 / 3$, sometimes with an apical spot. Hindwings $3 / 4$ in width, narrow-lanceolate, with a long frenulum near
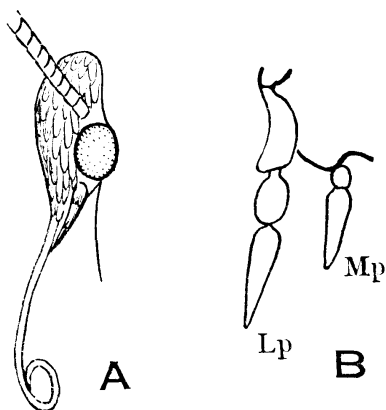

Fig. 1. Antispila purplella sp. nov.

A. Head., lateral view.

B. Labial palpus and maxillary palpus. base in male; cilia 2.

Venation: There are some exceptional species within the genus, of which there is found a conspicuous reduction of veins as seen in A. trypherantis Meyrick and A. cyclosema Meyrick. However, followings are the general characters : on forewing, lc not reaching dorsal margin; 3 absent; discocellulars slightly curved between 2 and 4-1-5 or not so; $4-\mathrm{t}-5$ from the middle of discocellulars, or near or just the upper apex of discoidal cell; 6 and $7+8$ stalked, $7+8$ to costa; 9 stalked with $7+8$ at some distance beyond the upper apex of discoidal cell or from the upper apex of discoidal cell; 11 emitted from near

$1 / 4$ of discoidal cell; sometimes a fine trachea running longitudinally in discoidal cell as a remnant of media. On hindwing, Ic not reaching dorsal margin; 2 and 3 stalked, or 2 absent; 6 and 7 stalked, 7 to costa or near' apex, sometimes 6 absent ; 4 diverging from before middle of wing; 8 highly curved at base.

Male genitalia : Scaphium weakly sclerotized, uncus undeveloped, with a hairy pad; gnathos consists of a pair of hairy tubercles; valva triangular or trapezoidal, with a comb of teeth, ampulla projected like a finger; saccus large and deep, U-shaped ; aedoeagus long and slender, with a peculiar shaped, moderately sclerotized phallobase (basal plate of phallus) which is in contact with its ventral side, and apex of aedoeaugs with various shaped terminal appendages ; anellus spined; transtilla and juxta present.

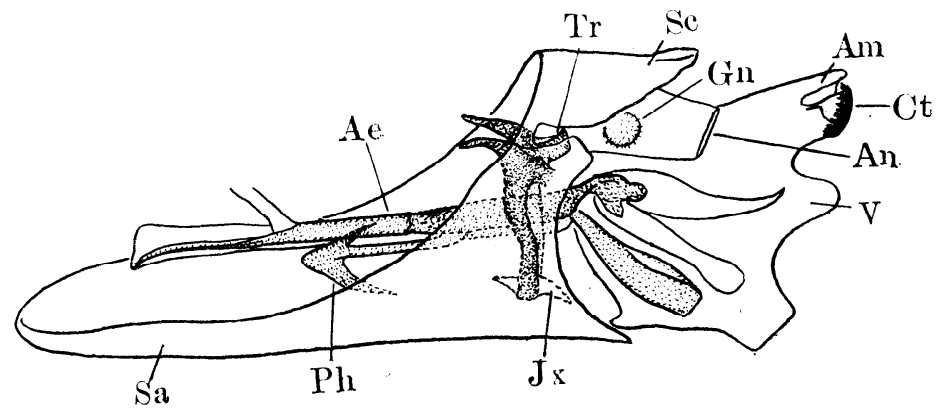

Fig. 2. Male genitalia of Antispila hikosana sp. nov., lateral view.

Ae: aedoeagus, Am: projection of ampulla, An: anus,

Ct: comb of teeth, Gn: gnathos, Jx: juxta, Ph: phall obase,

Sa: saccus, SC: scaphium, Tr: transtilla, $v$ : valva. 
Female genitalia : Single sex-opening type ; ovipositor specialized for piercing, and with several points; ductus bursae having an enlarged part with a pair of slightly sclerotized filaments and microscopical spines, sometimes with some sclerotized plates as signa; signa absent.

Habits of larvae and pupae: The larvae mine oblong or circular or irregular blotches in the leaves of host plants. When the larvae are full fed, they make an attempt to build their cases at the end or the center of the mine, and first line by silk the portions of the upper and lower epidermis of the leaf which will form both sides of their cases; soon after they commence to detach along the margin of those portions; simultaneously with proceed to detach the two epidermis from the leaf, they sew up the cut margins of those epidermis together. These epidermis convert into a flat case, when the epidermis are detached entirely from the leaf, and the cases descend to the ground; they convey their cases by means of silk for a little while, and the edges of the cases are fastened to such suitable places as surface of the earth, dead leaves or stems, by one or more silken strands. After settling the cases to the suitable places, the larvae spin their cocoons inside the cases, and then form several whitish thorn-like silken projections on the outside of edges of the cases. The larvae cast their skins and enter the non-feeding instar after a short time. They pass over the winter at this state, and change to the pupae in the following year. Before emergence of the adults, the pupae wriggle out to some extent from one end of the cases, therefore the empty pupal cases are remaining protruding from the cases.

\section{Key to the species}

1. Forewing with a transverse fascia at $1 / 3 \ldots \ldots \ldots \ldots \ldots \ldots$ - Forewing with twe opposite spots instead of a fascia. ......6

2. Wing markings pale golden-metallic, expanse very large ........

A. hikosana sp. nov.

- Wing makings silvery-metallic or nearly so ..........

3. Transverse fascia equidistance from base of wing, its posterior margin obscured

A. purplella sp. nov.

- Transverse fascia inwardly obliqued from costa, all markings distinct .. 4

4. Transverse fascia rather straight, sometimes posterior spots small, and reflections of forewings and markings are feeble ........

A. hidrangifoliella sp. nov.

- Transverse fascia slightly curved, posterior spots' nearly reaching half across wing, reflections of forewings and markings rather strong. ... 5

5. Transverse fascia rather broad, posterior dorsal spot bifurcated in disc .

A. obriculella sp. nov.

- Transversefascia moderately, posterior dorsal spot triangular .....

A. ampelopsia sp. nov.

6. All spots reaching half across wing, reflections of forewings rather strong

A. iviella sp. nov. 
- All spots not reaching half across wing, reflections of forewing moderate

A. corniella sp. nov.

Antispila orbiculella sp. nov.

(PI. 7, fig. 31; Pl. 8, fig. 38)

今ㅇ. 4.0-4.5 mm. Head, antennae, thorax and abdomen shining bronzy-fuscous. Palpi pale fuscous.

Forewings rather broad-lanceolate; discocellulars slightly curved between vein 2 and $4+5$, vein 4 -t-5 from middle of discocellulars, vein 9 from the upper apex of discoidal cell, dark bronzy-fuscous with reddish reflections; basal area shining leaden-bronze; markings silvery-metallic with yellowish or bluish reflections in some lights; a rather broad, slightly curved oblique transverse fascia at $1 / 3$; a rather large quadrilateral spot on costa at $2 / 3$, reaching nearly half across wing, a rather large opposite spot on dorsum, bifurcated in disc; cilia pale fuscous, basel half dark fuscous, its margin rounded. Hindwings, vein 2 absent, vein 6 and 7 stalked; pale fuscous, with feeble purplish lusters; cilia pale fuscous.

Male genitalia (PI. 4, fig. 11): Edge of scaphium slightly bilobed; valva trapezoidal ; ampulla moderately projected, slightly downward ; sacculus angulated ; saccus broad; apex of aedoeagus with some spines and two projections, one rounded at apex and another tapered; phallobase short, its apex broadly swollened.

Female genitalia (P1. 6, figs. 16 \& 24): Ovipositor five pointed, central point indent; enlarged part of ductus bursae with 2 pairs of plates, 1 pair of short bars and 1 pair of spined rows.

Holotype: $\hat{\text { o }}$ Mt. Hikosan, N. Kyushu, 1 July 1955 (H. Kuroko).

Allotype: $q$, the same as holotype, 1 July 1955 (H. Kuroko).

Paratypes : 1 \&, the same as holotype, 24 June 1955; 1 \&, 26 June 1955; 1 o, 2 July 1955; 1 s, 3 July 1955 (H. Kuroko).

Distribution : Japan (Kyushu \& Yakushima).

This new species is easily distinguishable from the other species by the rather broad transverse fascia and the bifurcated posterior dorsal spot. The larvae are not rarely found in autumn on Mt. Hikosan.

\section{Biological notes}

Host plant : Ampelopsisbrevipedunculata (Maxim.) Trautvetter (Jap. name : Nobudō).

Mine (P1. 9, fig. 45): Orthogenous blotch mine, full depth type; pale greenish brown, central area blackish brown, appearing just as disease blotch; 5-6 mm. in diameter. Usually one mine found on a single leaf, but sometimes 2-3 are found, and extending between two ribs of the leaf.

Frass: Blackish brown grains of frass are arranged in a circle around central area and some of frasses are smeared inside of epidermis of central area of the mine. 
Case (fig. 3) : Discal, central parts of both faces convex; dark brown ; 2.5$3.0 \mathrm{~mm}$. in diameter. Thorn-like projections more or less pointed; pale brown, $1-21$ in number; $0.09-0.12 \mathrm{~mm}$. in length. The case is cut out from the central part of the mine.

Development: One generation in a year. The larvae may be found feeding from the end of August to September; when they become full grown at the end of September, they cut out circular cases and descend to the ground; in case they hibernate as a non-feeding larval stage, pupation occurs at the end of May of the following year; the adults appear from the middle of June to the beginning of July.

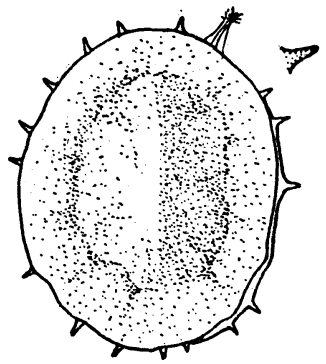

Fig. 3. Case of the larva of Antispila orbiculella sp nov.

Antispila ampelopsia $\mathrm{sp}$. nov.

(Pl. 7, fig. 32 ; Pl. 8, fig. 40)

ภㅇ․ 4.5-5.5 $\mathrm{mm}$. Head, antennae, thorax and abdomen shining bronzyfuscous, Palpi whitish.

Forewings, venation the same as in A. orbiculella Kuroko; dark bronzy-fuscous with reddish reflections; basal area shining leaden-bronze ; markings silverymetallic, with yellowish or bluish reflections ; slightly curved oblique transverse fascia moderately, constricted on fold, broad toward dorsum; posterior costal spot subtriangular or rectangular, and opposite dorsal spot placed slightly before costal spot, triangular and nearly reaching half across wing; cilia pale fuscous, basal half dark fuscous with purplish reflections. Hindwings, veins 2 and 6 absent, vein 7 to near apex; fuscous with purplish lusters feebly; cilia pale fuscous.

Male genitalia (Pl.5, fig. 14); Scaphium trapezoidal ; valva triangular, projection of ampulla well developed and broadened ; sacculus swollen; basal edge of saccus prolonged at middle; apex of aedoeagus with two finger-shaped projections and a membranous projection bearing a bifurcated, spined piece; phallobase spear-shaped.

Female genitalia (Pl. 6, figs. 18 \& 26) : Ovipositor seven pointed, central point deeply indent; enlarged part of ductus bursae with two oblong plates and a curved plate.

Holotype: ô, Mt. Hikosan, N. Kyushu, 11 Aug. 1956 (H. Kuroko).

Allotype: of, the same as holotype, 24 June 1955 (H. Kuroko).

Paratypes : 2 우, the same as holotype, 14 \& 15 Sept. 1954; 1 ㅇ, 13 Aug. $1956(\mathrm{H}$. Kuroko). The following paratypes were bred in $25^{\circ} \mathrm{C}$ during the winter. 2 ofo, A mbo, Yakushima, 5 \& 11 Feb. 1960 (H. Kuroko).

Distribution: Japan (Kyushu \& Yakushima).

This new species differs from A. ampelopsiella Chambers, A. ampelopsifoliella Chambers and A. voraginella Braun of which the larvae are known as the leaf- 
miner of Ampelopsis or Vitis in N. America, by the absence of the apical spot. This species is similar to A. isablella Clemens from $\mathrm{N}$. America, but being smaller and having the posterior dorsal spot triangular. From A. viticordifoliella Clemens this species is distinguishable by the absence of silvery-white joints at the apex of the antennae. The larvae are commonly found in autumn on Mt. Hikosan.

\section{Biological notes}

Host plants: Ampolopsis brevipedunculata Maxim). Trautvetter (Jap. name : Nobudō), Vitis flexuosa Thunberg (Jap. name: Sankakuzuru).

Mine (PI. 9, fig. 46): Blotch mine, full depth type ; semitransparent, whitish, faintly tinged with yellowish green; feeding area 74-120 $\mathrm{mm}$ ? Usually extending at the apical area or marginal area of the leaf, and one mine is made on a single leaf.

Frass: Blackish grains of frass are scattered more or less in a zigzag line.

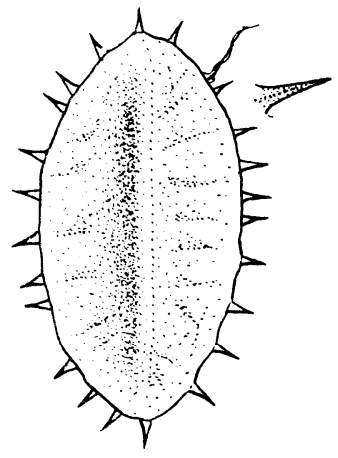

Fig. 4. Case of the larva of Antispila ampelosia sp. nov.

Case (fig. 4): Elliptical, with a longitudinal ridge at the middle of each face; brown to dark brown; $3.5 \times 1.2 \mathrm{~mm}$. $-4.0 \times$ $2.0 \mathrm{~mm}$. in size. Thorn-like projections pointed and radiating; brown ; 11-24 in number; 0.3-0.42 mm. in length. The case is cut out from the end of the mine.

Development: Number of generations unknown, but the larvae are found at the end of July, at the middle of August and from the end of September to the middle of October, and the adults appear at the middle of August, at the middle of Septem. ber and at the end of June. Therefore, it may be apparent that this new species repeats two or three generations in a year. If it is so, this habit may be exceptional.

Antispila corniella sp. nov.

(Pl. 7, fig. 33 ;Pl. 8, fig. 41 )

of , 5 - $6 \mathrm{~mm}$. Head, antennae and thorax shining bronzy-fuscous. Palpi whitish. A.bdomen bronzy-fuscous above, shining white beneath.

Forewings, venation as in A. ampelopsia Kuroko, but vein 9 stalked with vein $7+8$ at a short distance beyond the upper apex of discoidal cell; dark bronzyfuscous with brassy reflections, becoming purplish reflections on the apical half; basal area shining leaden-fuscous; makings silvery-metallic with yellow or bluish reflections ; a subtriangular costal spot at $1 / 3$, and a triangular dorsal spot slightly before the costal spot; a similar posterior costal spot at near $2 / 3$, and dorsal spot slightly before just mentioned costal spot; both costal spots 
not reaching half across wing but two dorsal spots reaching half; cilia pale fuscous, basal half dark fuscous. Hindwings, venation the same as in $\boldsymbol{A}$. ampelapsia Kuroko; pale fuscous with feeble purplish lusters ; cilia pale fuscous.

Male genitalia (PI. 5, fig. 15): Edge of scaphium convexed at middle; valva triangular, with a rather large comb of teeth; projection of ampulla short, straightened; saccus prolonged and rather narrow; apex of aedoeagus with two pouch-shaped projections ; phallobase spear-shaped, apex not pointed.

Female genitalia (PI. 6, figs. 22 \& 23): Ovipositor five pointed, central point indent; enlarged part of ductus bursae with two conspicuous filaments, bearing a basal 'knot.

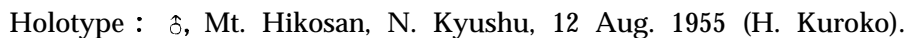

Allotype: o, the same as holotype, 3 Aug. 1956 (H. Kuroko).

Paratypes: 1 , the same as holotype, 25 July 1955; 1 o, 2 \%o, I-5 Aug. 1956 (H. Kuroko).

Distribution : Japan (Kyushu).

The present new species is allied to A. treitschkiella Fischer von Röslerstamm of which the larva is known as a leaf-miner of Cornus in Europe, but in the latter species the forewing has a transverse fascia instead of anterior spots, and the projection of ampulla is much longer.

\section{Biological notes}

Host plants: Corms controversa Hemsley (Jap. name : Mizuki), C. brachypoda C. A. Mey. (Jap. name: Kumano-mizuki).

Mine (PI. 9, fig. 47) : Linear-blotch, full depth type; linear mine whitish, semitransparent, extends in a line along the leaf margin or a wavy line and becoming gradually broader; about $35 \mathrm{~mm}$. in length. After the 3rd moult, the mine develops into a whitish green blotch, with greenish grains by feeding tracks; feeding area $156-192 \mathrm{~mm}^{2}$. One or two mines are found on a single leaf.

Frass: Blackish grains of frass, in linear mine arranged in a line, but in blotch mine appearing like a large black patch in the middle of the mine.

Case (fig. 5) : Elliptical, with a Iongitudinal ridge at the middle of each face; brown to dark greyish brown; $4.0 \times 2.0 \mathrm{~mm}$. $-4.0 \times 2.5$ $\mathrm{mm}$. in size. Thorn-like projections triangular and radiating; brown; $10-20$ in number; $0.18-0.3 \mathrm{~mm}$. in length.

Development: One generation in a year. The larvae may be found feeding from the September to October; the cases are cut out from the end of mine and the larvae descend to the ground; the larvae hibernate as a

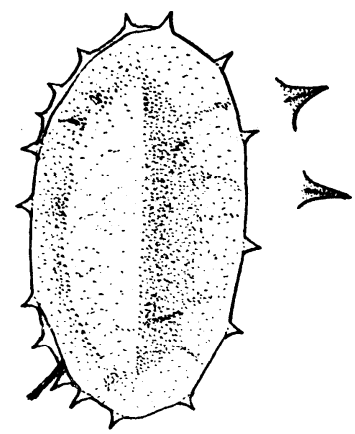

Fig. 5. Case of the larva of Antispila corniella sp. nov. 
non-feeding larval stage, and change to pupae at the beginning of June of the following year; the adults appear from the end of July to August.

\section{Antispila iviella sp. nov.}

(Pl. 7, fig. 34 ;Pl. 8, fig. 41)

9. 5--6 mm. Head, antennae and thorax shining dark bronzy-fuscous. Palpi. whitish. Abdomen dark brozy-fuscous above, sivery-whitish beneath.

Forewings, vein $4+5$ from near the upper apex of discoidal cell, vein 9 stalked with vein $7+8$ at some distance beyond the upper apex of discoidal cell ; dark bronzy-fuscous with brassy reflections, becoming purplish reflections towards apex and termen; basal area shining dark leaden; markings rather raised and silvery-metallic tinged with faint golden; a subtriangular or oblong costal spot at $1 / 3$, and a triangular dorsal spot slightly before costal spot; a similar posterior costal spot at near $2 / 3$ and a dorsal spot slightly before posterior costal spot; all spots almost reaching half across wing; cilia fuscous, basal half dark fuscous with strong purplish reflections. Hindwings, vein 2 absent, veins 6 and 7 stalked at near apex; pale fuscous with feeble lusters ; cilia pale fuscous

Female genitalia (Pl. 6, figs. $17 \& 25)$ : Ovipositor similar to that of the preceding species; enlarged part of ductus bursae with a sclerotized loop.

Holotype: + , Miyanoura, Yakushima, 14 July 1960 (H. Kuroko).

Paratypes : 1 \%, the same as holotype, 13 Feb. 1960; 1 ㅇ, 22 July 1960 (H. Kuroko). All the specimens were bred under $25^{\circ} \mathrm{C}$ during the winter.

Distribution : Japan (Yakushima).

This new species is closely allied to A. argostoma Meyrick, of which the larva is known as a leaf-miner of Vitis in India, but separable from it by golden-metallic markings.

\section{Biological notes}

Host plant : Parthenocissus tricuspidata (Sieb. et Zucc.) Planchon (Jap. name : Tsuta).

Mine (fig. 6) : Linear-blotch, full depth type; the larva at first making whitish brown linear mine, proceeds in an irregular wavy gallery, sometimes spiral at the beginning; about $60 \mathrm{~mm}$. in length. After continuing to feed in this linear track for some distance, the mine develops rather abruptly into a pale brown irregular blotch ; feeding area about $284 \mathrm{~mm}^{2}$.

Frass: Blackish brown grains of frass arranged in a line along the center of the linear mine, but in blotch mine being scattered a large pale brown patch in the middle of the mine.

Case : Elliptical, with a longitudinal ridge at the middle of each face; brown to dark brown; $3.5 \times 1.8 \mathrm{~mm}$. $-4.4 \times 2.6 \mathrm{~mm}$. in size. Thorn-like projections. pointed and arranged near both ends; whitish to pale brown ; 9-16 in number; $0.36-0.48 \mathrm{~mm}$. in length. The cases are settled to some suitable places by one or two silken strands.

Development: Number of generations unknown, but the larvae were collected on the leaves of the host plant at the end of October on Yakushima; they 
passed the winter as a non-feeding larval stage, and appeared in July of the following year.

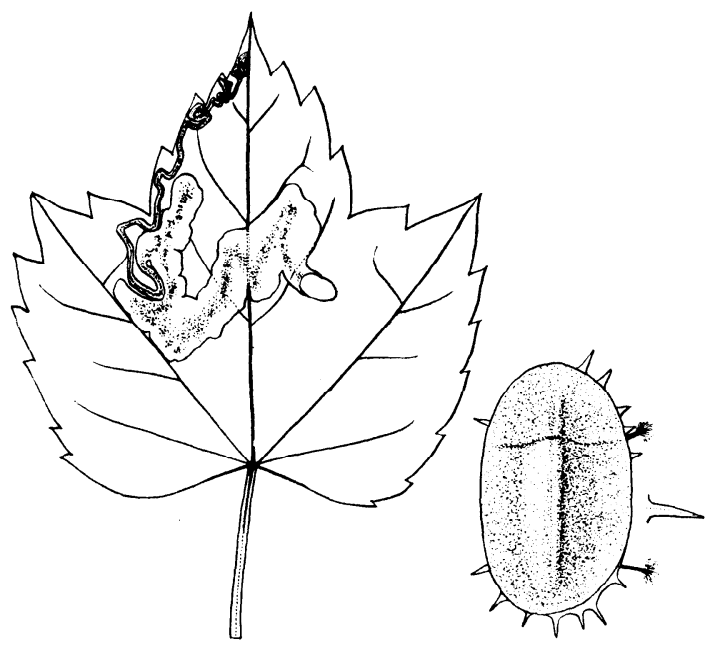

Fig. 6. Leaf of Parthenocissus tricuspidata Planchon mined by the larva of Antispila iviellasp. nov. and the larval case.

Antispila hikosana sp. nov.

(PI. 7, fig. 36; Pl. 8, fig. 44)

so. 8-9 mm. Head, antennae, thorax and abdomen shining bronzy-fuscous. Palpi pale ochreous.

Forewings, vein $4+5$ from near the upper apex of discoidal cell, vein 9 stalked with $7+8$ at some distance beyond the upper apex of discoidal cell; bronzy-fuscous with coppery reflections, becoming purplish reflections towards apex; basal area shining dark leaden-fuscous ; markings pale golden-metallic ; oblique transverse fascia rather narrow, constricted on fold and broadened towards dorsum, rarely interrupted in disc; posterior costal spot triangular, not reaching half across wing, and dorsal spot rather large triangular, slightly before costal spot, reaching half across wing; cilia pale greyish fuscous, basal half bronzy-fuscous with brassy reflections. Hindwings, veins 2 and 6 absent, vein 7 near apex; pale $f$ uscous with feeble purplish lusters; cilia pale fuscous.

Male genitalia (fig. 2; Pl. 4, fig. 10): Edge of scaphium slightly concave at middle ; valva with two swellings at posterior margin; projection of ampulla short and slender ; apex of aedoeagus with a bifurcated appendage and a pouchshaped projection; phallobase anchor-shaped.

Female genitalia (P1. 6, figs. $20 \& 28$ ): Ovipositor five pointed, edge of the points straightened, center point indent; enlarged part of ductus bursae with 
two intricated patterns and many microscopical spines.

Holotype: ô, Mt. Hikosan, N. Kyushu, 21 Apr. 1956 (H. Kuroko).

Allotype: o, the same as holotype, 21 Apr. 1956 (H. Kuroko).

Paratypes: $2 \hat{\circ}, 2$ 우, the same as holotype, 21 Apr. 1956; $1 \hat{\jmath}, 1$ ?, 23 Apr.. 1956 (H. Kuroko).

Distribution : Japan (Kyushu).

This new species is most closly related to A. pfeifferella Hübner of which the larva is known as a leaf-miner of Cornus in Europe, but separable from the latter in having coppery reflections on the forewings and rather shorter, projection of ampulla in male.

\section{Biological notes}

Host blants : Cornus controversa Hemley (Jap. name : Mizuki), C. brachypoda C. A. Mey. (Jap. name : Kumano-mizuki).

Mine (fig. 7): Linear-blotch, full depth, similar to that made by the larva of A. corniella Kuroko, but much larger; linear mine extends along the leaf
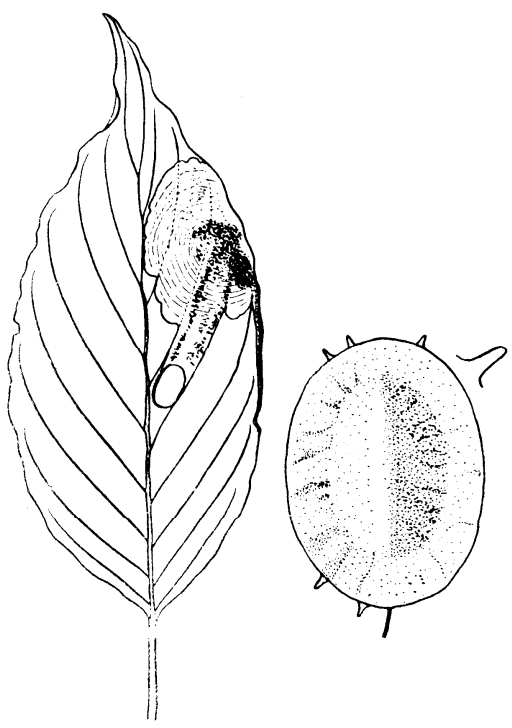

Fig. 7. Leaf of Corms brachypoda C. A . Mey. mind by the larva of Antispila hikosana sp. nov. and the larval case.

Devel opnent : One generation in a year. The larvae feed from the end of May to June; the cut cases descend to the ground at the beginning of July; the larvae hibernate as a non-feeding larval stage in their cases and change to. 
pupae in the spring of the fol lowing year; the adults appear from the end of April to the beginning of May.

\section{Antispila hydrangifoliella sp. nov.}

(Pl. 7, fig. 35 ; P1. 8, fig. 39)

s o. 5-6 mm. Head, antennae, thorax and abdomen shining bronzy-fuscous. Palpi pale ochreous.

Forewings, venation as in A. hikosana Kuroko; dark bronzy-fuscous, reflections feeble ; basal area shining leaden-bronze ; markings silvery-white, metallic reflections feeble; transverse fascia moderately to rather narrow and nearly straight; posterior costal spot and dorsal spot moderately to rather small, sometimes becoming nearly to dot; cilia pale grey, besal half dark bronzyfuscous. Hindwings, veins 2 and 6 absent, vein 7 to near apex of the wing; pale fuscous, with feeble purplish lusters; cilia pale fuscous.

Male genitalia (PI. 5, fig. 13) : Edge of scaphium rounded ; ampulla moderately projected, slightly downward ; sacculus swollened ; saccus V-shaped; apex of aedoeagus with two mushroom-shaped and a clavate appendages; phallobase spear-shaped.

Female genitalia (Pl.6, figs. 19 \& 27): Ovipositor with about 14 blunt serrations; enlarged part of ductus bursae with many wrinkles aud winding fillets.

Holotype: s, Mt. Hikosan, N. Kyushu. 24 July 1954 (H. Kuroko).

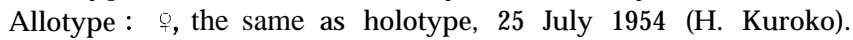

Paratypes: 2 우, the same as holotype, 15\& 23July 1954; 2 우, 28 \& 29 July 1957; 1 ;, 9 Aug. 1957 (H. Kuroko).

Distribution : Japan (Kyushu).

This species is allied to A. hydrangaeella Chambers, of which the Iarva is known as a leaf-miner of Hydrangea in N. America, but the apical spot is absent in the new species. The larvae may be observed in large numbers on $\mathrm{Mt}$. Hikosan at the end of autumn.

\section{Biological notes}

Host plants: Hydrangea macrophylla (Thunb.) Sering var. acuminata (Sieb. et Zucc.) Makino (Jap. name : Yama-ajisai), H. petiolaris Siebold et Zuccarini (Jap. name : Gotbzuru).

Mine (PI. 9, fig. 48): Linear-blotch, full depth type; linear mine pale yellowish green to pale brown, semitransparent; about $80 \mathrm{~mm}$. in length ; proceeds in an irregular wavy gallery, somewhat confined by ribs. After 3rd moult, the mine expands into an irregular, semitransparent, whitish green blotch, often along the leaf margin; feeding area 224-264 $\mathrm{mm}$ ? Usually one mine is found on a single leaf, sometimes 2 mines are made.

Frass: Blackish grains of frass form a scattered row occupying nearly the whole of the linear mine, but in blotch mine they are thinly scattered, sometimes deposited along the margin of the mine. 


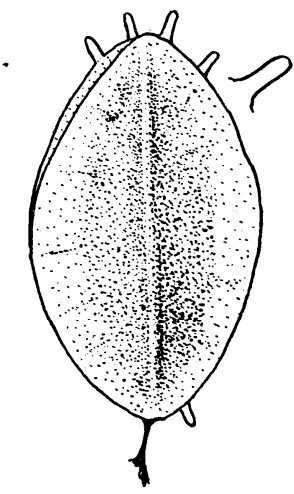

Fig. 8. Case of the larva of Antispila hydrangifoliella sp. nov.
Case (fig. 8) : Elliptical, broadened at the middle of both sides, with a longitudinal ridge at the middle of each face; light brown ; $4.0 \mathrm{x}$ $2.5 \mathrm{~mm}$. $-4.5 \times 2.7 \mathrm{~mm}$. in size. Thorn-like projections rounded and arranged near both ends; whitish; 3-7 in number; 0.3-0.42 $\mathrm{mm}$. in length.

Development: One generation in a year, The larvae feed from the middle to the end of October, pass the winter as a non-feeding larval stage in the cut cases; pupation occurs at the middle of July, and the adults appear from the end July to the beginning of August.

\section{Antispila purplella sp. nov.}

(Fig. 1; P1. 7, fig. 37; P1. 8, fig. 43)

今ㅇ. 6.5-7.5 mm. Head, antennae, thorax and abdomen shining bronzy-fuscous. Palpi pale fuscous.

Forewings, vein $4+5$ from the upper apex of discoidal cell, vein 9 stalked with $7+8$ at some distance beyond the upper apex of discoidal cell; dark bronzy-fuscous with reddish or purplish reflections; basal area shining dark leaden-fuscous; makings silvery-metallic with somewhat coppery reflections ; transverse fascia slightly curved but not obliqued, its posterior margin obscured and with purplish lusters; posterior costal spot triangular, rather small, and dorsal spot narrow triangular, barely reaching half across wing; cilia fuscous, basal half with reddish or purplish reflections. Hindwings, veins 2 and 3 stalked, veins 6 and 7 stalked; fuscous with feeble purplish lusters; cilia pale fuscous.

Male genitalia(Pl.4, fig. 12) : Edge of scaphium slightly convexed at middle; valva nearly triangular; ampulla rather prolonged, slightly upward; comb of teeth rather large; sacculus with a small swelling; basal edge of saccus with a triangular sclerotized plate; apex of aedoeagus with a bended plate, a pouchshaped appendage and a bifurcated appendage; apex of phallobase nearly equilateral triangle.

Female genitalia (P1. 6, figs. 21 \& 29): Ovipositor five pointed, edge of points rounded, central point indent; enlarged part of ductus bursae with two conspicuous filaments and twin intricated patterns.

Holotype: ô, Mt. Hikosan, N. Kyushu, 3 June 1956 (H. Kuroko).

Allotype:

Paratypes : $4 \hat{\jmath} \hat{\imath}, 4$ 우우, the same as holotype, I-4 June 1956 (H. Kuroko).

Distribution : Japan (Kyushu).

This new species is easily distinguishable from the other species by the transverse fascia not oblique. 


\section{Biological notes}

Host plants: Cornuscontroversa Hemsley (Jap. name : Mizuki), C. brachypoda C. A. Mey. (Jap. name: Kumano-mizuki).

Mine and frass: Similar to those made by the larva of A. hikosana Kuroko, but the mine of this species being made in autumn.

Case (fig. 9) : Elliptical, with a longitudinal ridge at the middle of each face; dark greyish brown; $4.2 \times 2.3 \mathrm{~mm}$. $-4.9 \times 3.0 \mathrm{~mm}$. in size. Thorn-like projections pointed and arranged near both ends; pale brown ; 8-19 in number; $0.18-0.36 \mathrm{~mm}$. in length.

Development : One generation in a year. The larvae feed from the end of September to the beginning of October; when full fed, the larvae fall to the ground with the cut cases, and change to pupae at the end of May of the following year; the adults appear at the beginning of June.

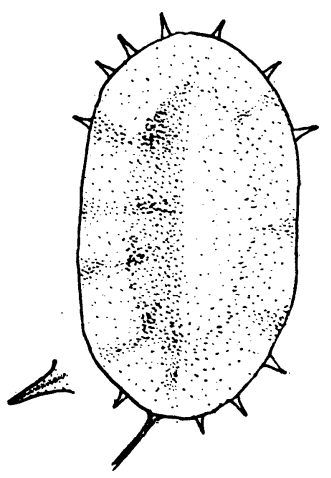

Fig. 9. Case of the larva of Antispila purplella sp. nov.

\section{Explanation of Plates \\ Plate 4}

Male genitalia, showing scaphium, valva, saccus and aedoeagus.

Fig. 10. Antispila hikosana sp. nov.

Fig. 11. Antispila orbiculella sp. nov.

Fig. 12. Antispila purplella sp. nov.

\section{Plate 5}

Male genitalia, showing the same parts as Plates 4.

Fig. 13. Antispila hydrangifoliella sp. nov.

Fig. 14. Antispila ampelopsia sp. nov.

Fig, 15. Antispila corniella sp. nov. 
Plate 6

Female genitalia, showing enlarged part of ductus bursae and ovipositor.

Figs. 16 \& 24. Antispila orbiculella sp. nov.

Figs. 17 \& 25. Antispilaiviella sp. nov.

Figs. 18 \& 26. Antispilaampelopsia sp. nov.

Figs. 19 \& 27. AntispiZa hydrangifoliella sp. nov.

Figs. 20 \& 28. Antispila hikosana sp. nov.

Figs. $21 \&$ 29. Antispila purplella sp. nov.

Figs. 22 \& 23. Antispilacorniella sp. nov.

Plate 7

Venation

Fig. 30. Antispila pfeifferella Hiibner

Fig. 31. AntispiZa orbiculella sp. nov.

Fig. 32. AntispiZa ampelosia sp. nov.

Fig. 33. AntispiZa corniella sp. nov.

Fig. 34. Antispilaiviella sp. nov.

Fig. 35. Antispila hydrangifoliella sp. nov.

Fig. 36. Antispila hikosana sp. nov.

Fig. 37. Antispila purplella sp. nov.

\section{Plate 8}

Fig 38. Antispila orbiculella sp. nov.

Fig. 39. Antispila hydrangifoliella sp. nov

Fig. 40. Antispila ampelopsia sp. nov.

Fig. 41. Antispila corniella sp. nov.

Fig. 42. Antispilaiviella sp. nov.

Fig. 43. Antispila purplella sp. nov.

Fig. 44. Antispila hikosana sp. nov.

Plate 9

Fig. 45. Leaf of Ampelopsis brevipedunculata Trautvetter mined by the larva of Antispila orbiculella sp. nov.

Fig. 46. Leaf of Ampelopsis brevipedunculata Trautvetter mined by the larva of Antispiza ampelopsiasp. nov.

Fig. 47. Leaf of Cornusbrachypoda C. A. Mey. mined by the larva of Antispila corniella sp. nov.

Fig. 48. Leaf of Hydrangea macrophylla Seringe var. acuminata Makino mined by the larva of Antispilahydrangifoliella sp. nov. 
0
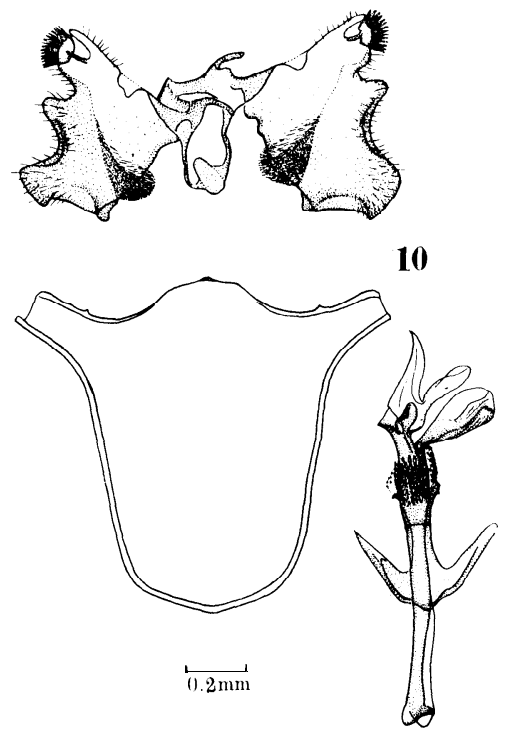

Dif

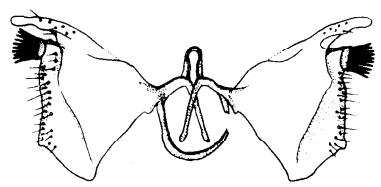

11
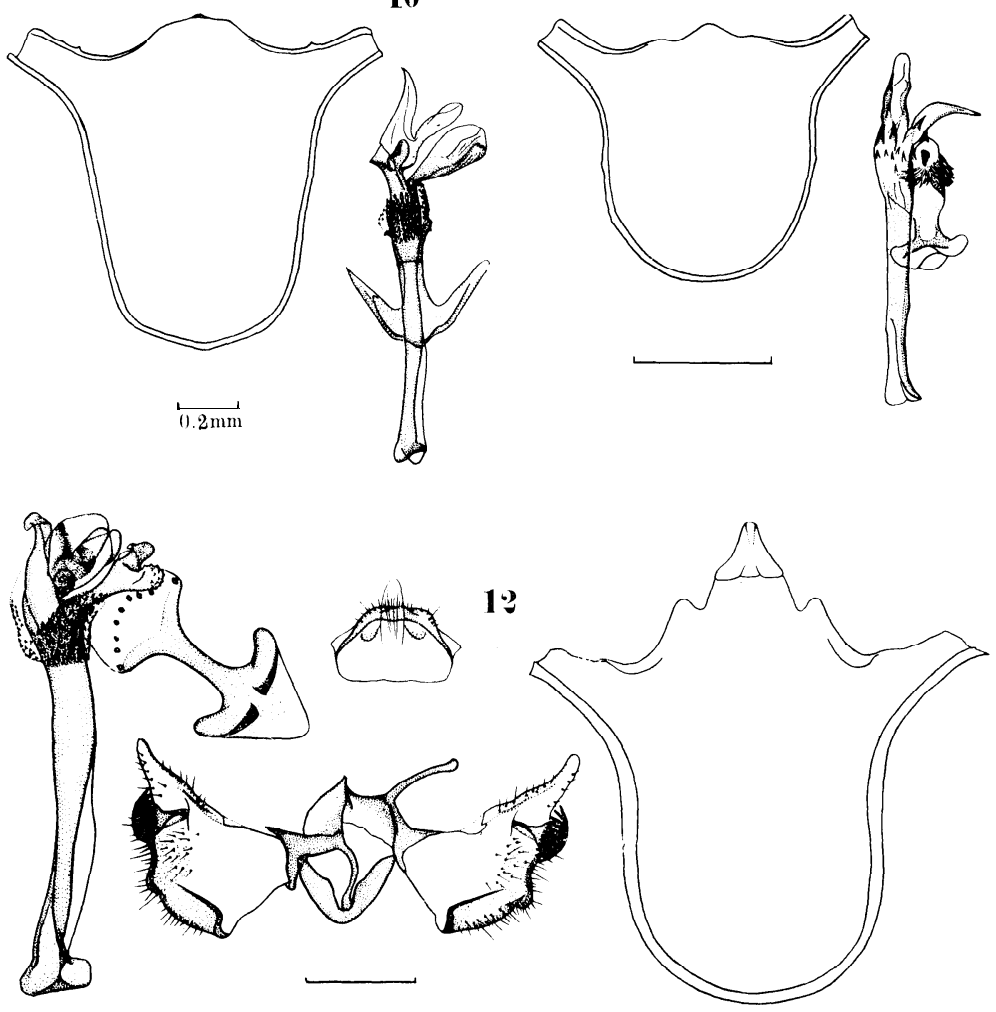

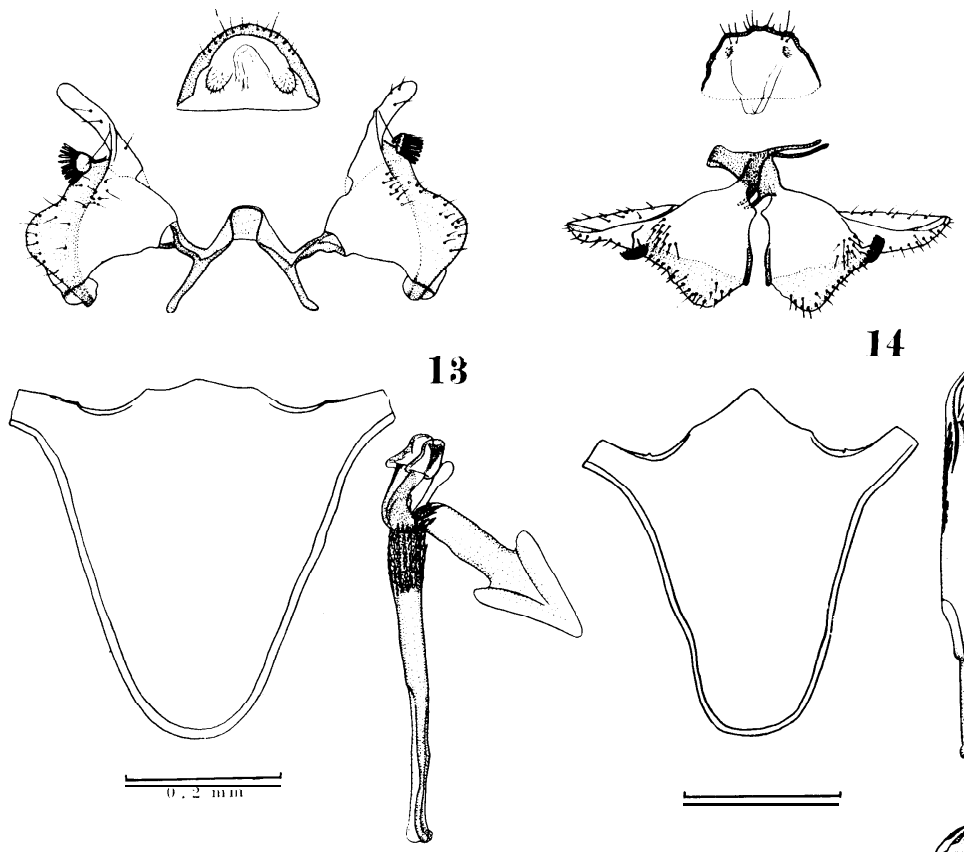

14

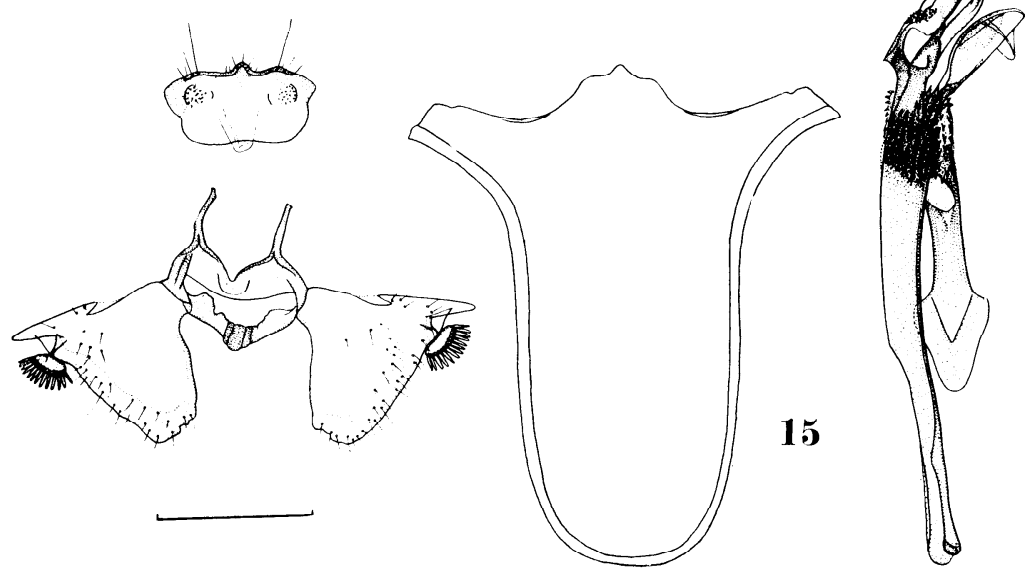




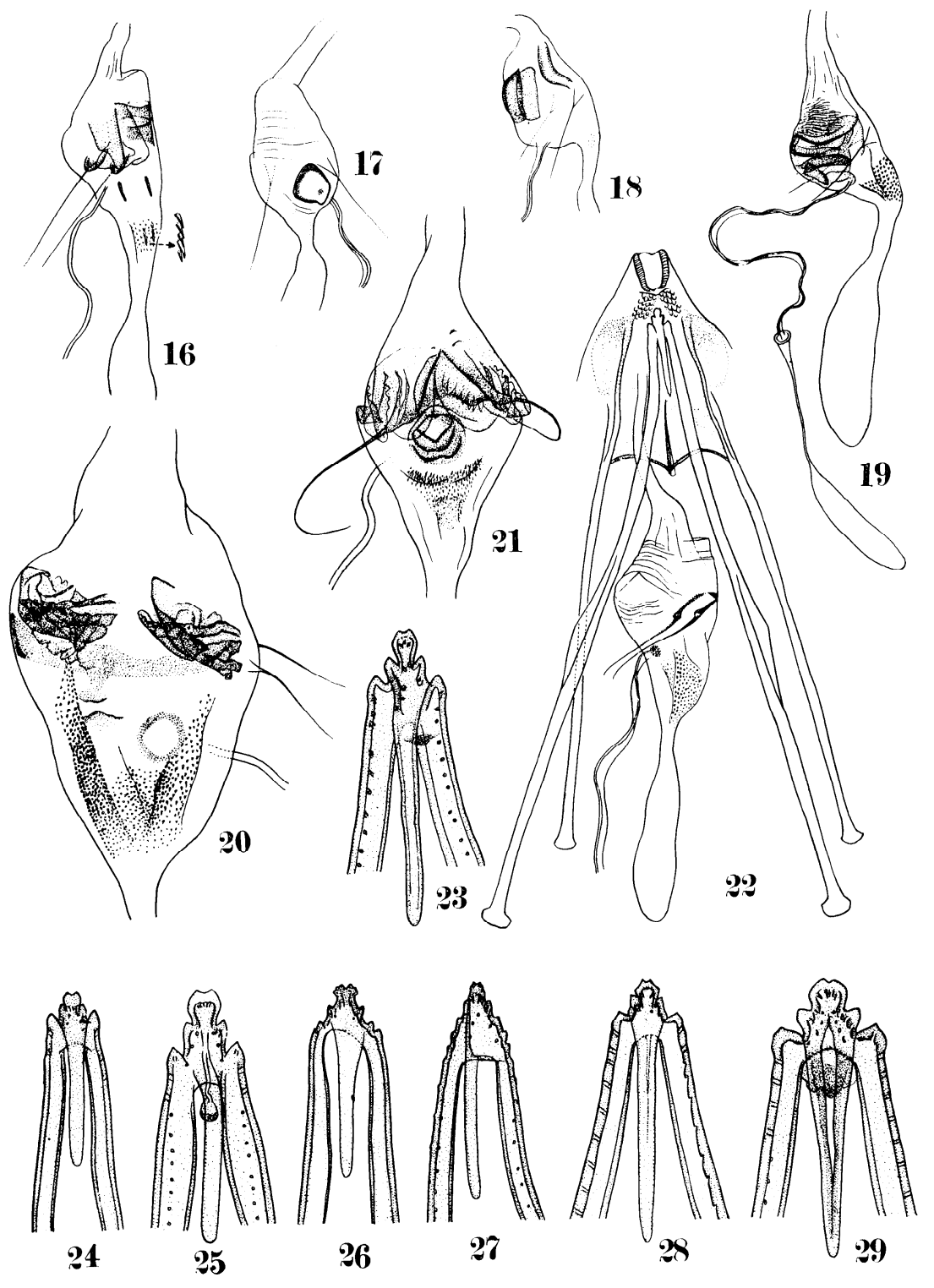




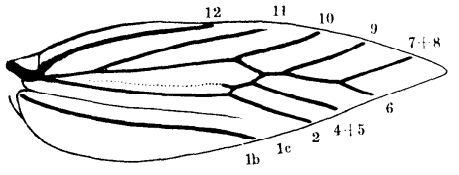

30
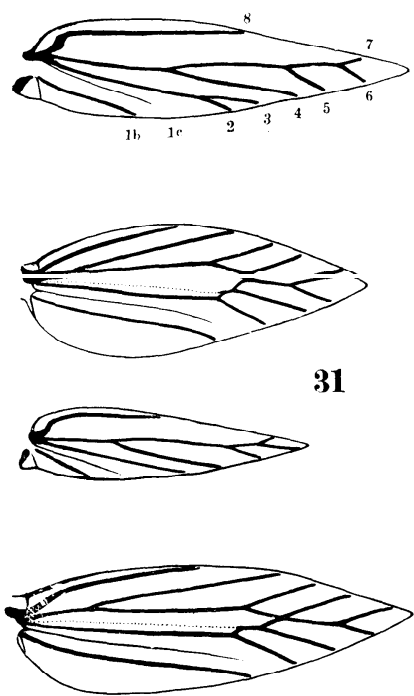

32
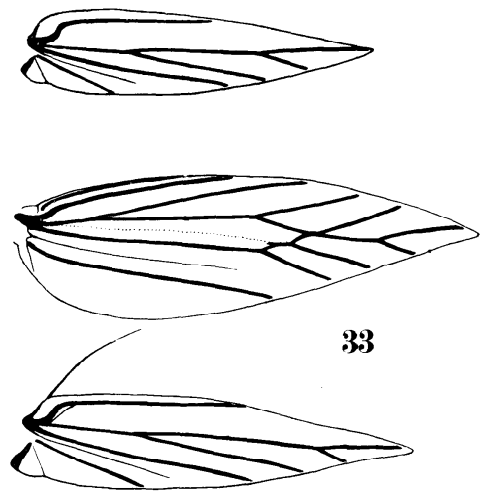

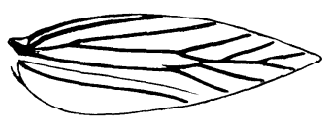

34
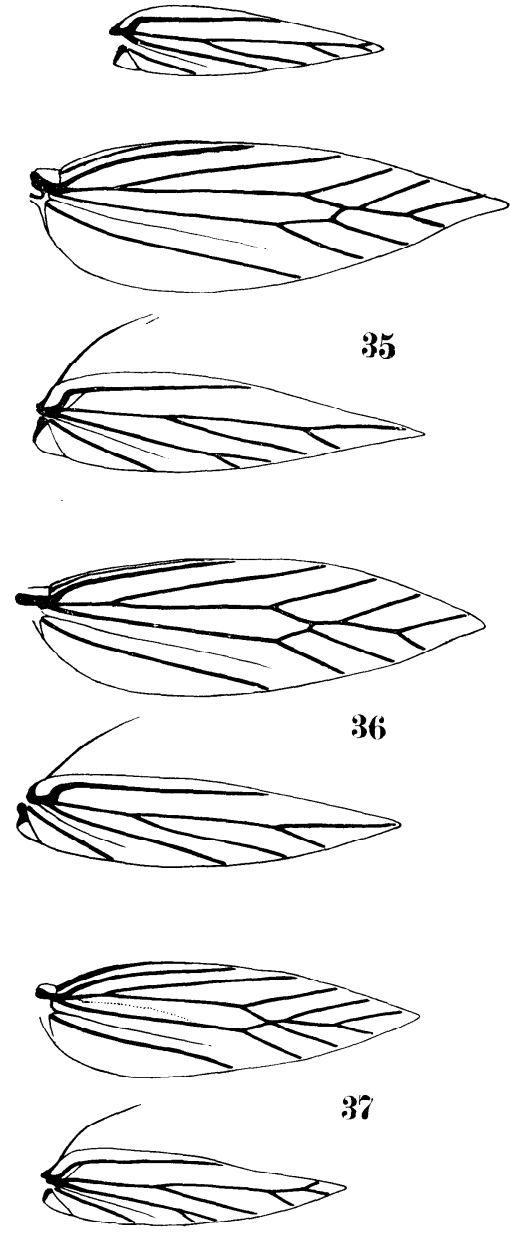
Esakia No. 3, 1961
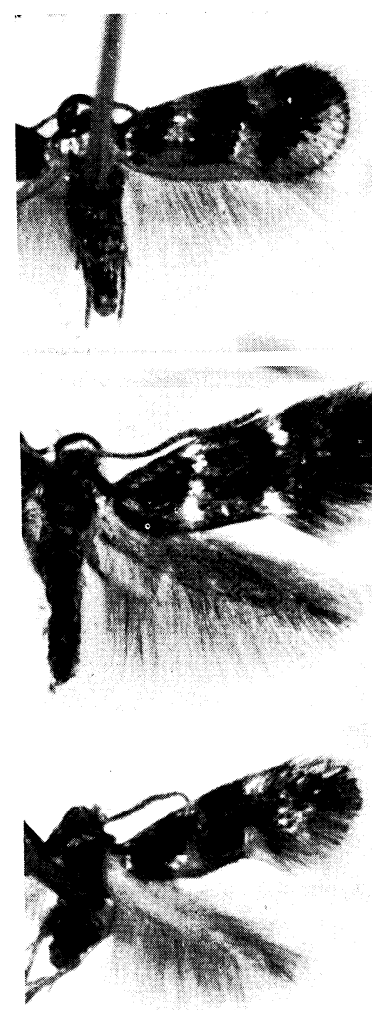

38

39

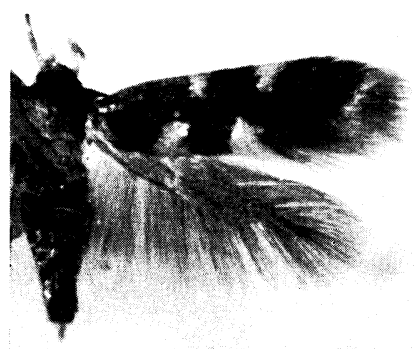

40

41
P late 8

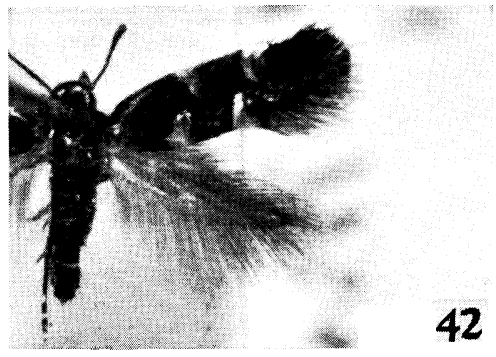

42
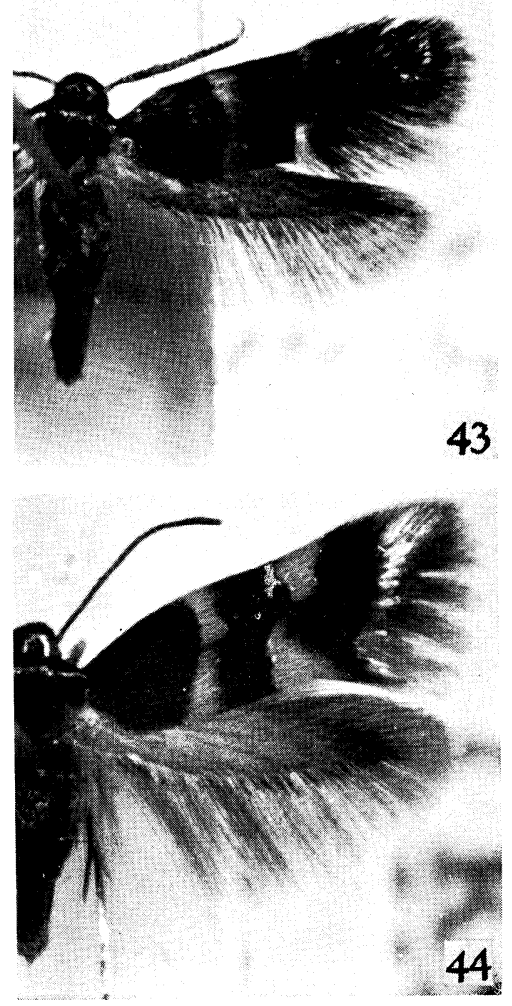


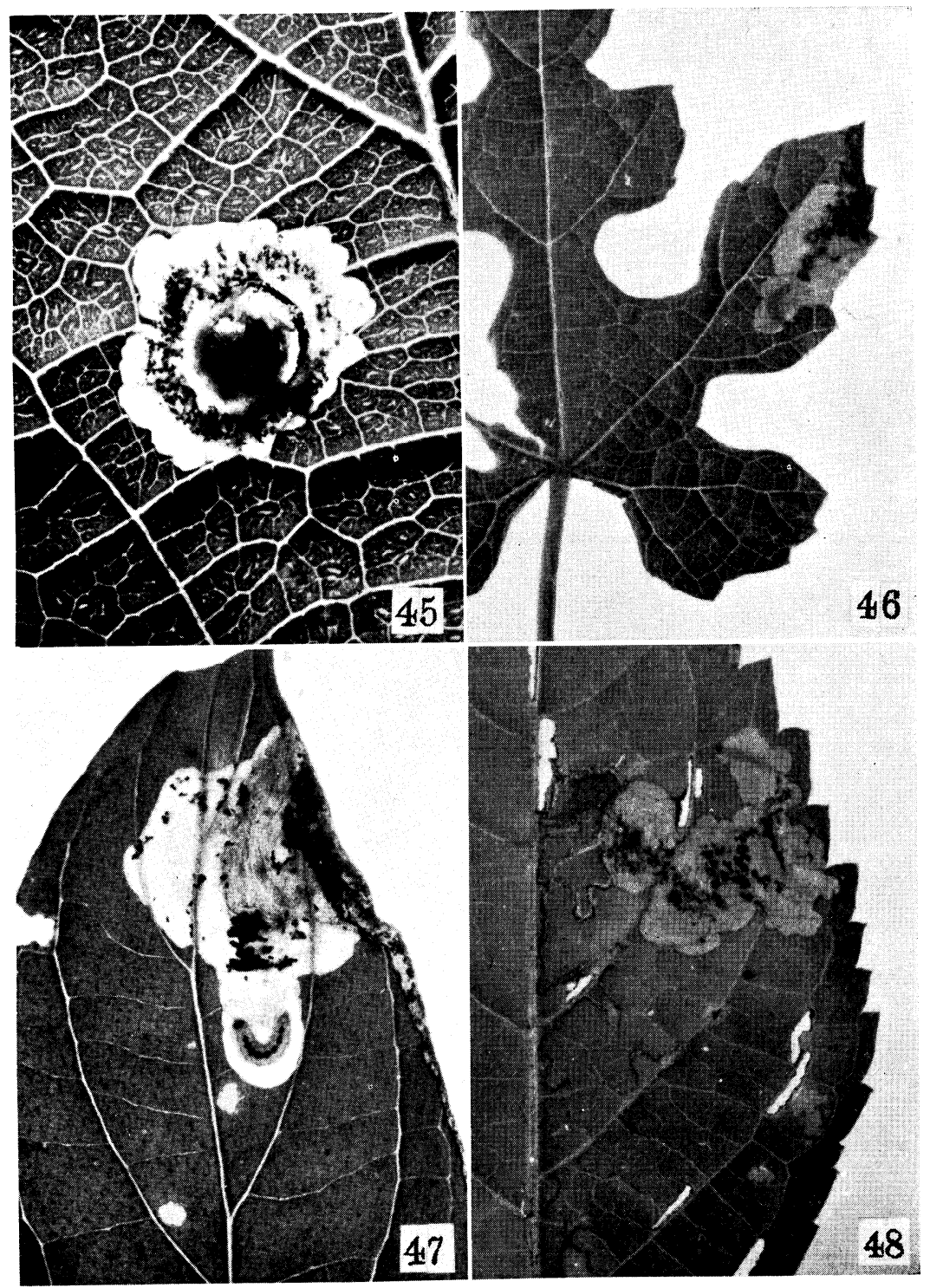

